\title{
Cross-sector partnership as a determinant of development - the perspective of public management
}

Joanna Wyrwa, Ph.D. University of Zielona Góra Faculty of Economics and Management

\section{Introduction}

The characteristic of each organized action or activity is collaboration, which is determined by different links between individuals and social groups working together towards a common goal. In the functioning of any modern public organization, collaboration is a prerequisite for achieving goals, although it is also an area that presents many difficulties (Kożuch 2007, p. 213). B. Kożuch distinguishes two forms of cooperation, i.e. collaboration and confrontation. Collaboration is understood as cooperation involving the implementation of common or convergent objectives, in particular with respect to coordination of implemented projects and functions established as part of the division of labor, whereas confrontation is conceived as activities consisting in rivalry or combat that assume different forms of competition in practice (Kożuch 2011, pp. 109110).

A modern approach to the problem of providing social services consists in arranging collaboration between various entities. Collaboration is no longer limited to just one sector, but increasingly often involves 
cross-sector agreements ${ }^{1}$ (Domański, Kitzman 2016, p. 56) and may lead to complementarity and synergy of otherwise scattered resources (Kachniarz 2014, pp. 46-47). A. Frączkiewicz-Wronka (2013, p. 169) emphasizes that "from the standpoint of public management pragmatics, promoting the idea of active social policy means searching a new way to provide services both by improving the performance of existing institutions as well as by configuring various organizations and developing inter-organizational networks". Establishing collaboration between various sectors can be considered an innovation in the social management process, which contributes to accomplishing goals more than the current way of proceeding. Observation of current practice indicates that organizations working together, pursuing common goals and consequently deciding on how to use their own resources often gain the ability to develop new structures. These structures - as a result of taking advantage of the benefits stemming from the implementation of the idea of cooperation - are able to generate together more positive results than each of the organizations separately (Frączkiewicz-Wronka 2014, p. 392).

New forms of collaboration, including mostly partnerships, are the realization of cooperation - joint, integrated and long-term undertakings, with various entities striving, first, to achieve appropriate operational efficiency by combining forces and resources, and second, to achieve synergistic effect. The premise of partnership lies in the assumption that it is one of the most effective ways of solving social problems as well as overcoming institutional divisions and isolation. It is, therefore, a kind of process of creating permanent links between entities, and thus prompt group decision-making geared towards consensus, an agreement in the area of priority goals and ways to accomplish them (KalisiakMędelska 2013, pp. 73-74).

Participants of partner initiatives are organizations that, collaborating with each other in formulating and implementing a local development program, are more active in this respect than others, feel the need to influence local development and consider themselves competent enough to initiate and fulfill tasks aimed at improving the quality of life of the local community. As the basic characteristics of partners one can distinguish, above all, the ability to define the goals and needs of social development and having a specific vision of the course of that development, given that the overriding obligation of organizations entering into

1 Terms such as "co-management in networks", "cooperation-oriented networks", „interorganizational networks", ,social networks" are indicated in the public administration literature.

Cross-sector partnership as a determinant of development - the perspective of public 
partnerships is to act on behalf of the interests of the whole community and institutions important to it (Frączkiewicz-Wronka 2014, p. 398).

Cooperation of public authorities with other entities, with a focus on achieving common objectives, gives rise to a network of material and non-material relationships. Analysis of the inter-organizational collaboration network allows to identify multilateral impacts of many factors, and it also facilitates assessing the situation and making decisions in the environment of uncertainty and constant changes (Sienkiewicz-Małyjurek 2012, p. 53).

Inter-organizational collaboration relies on the ability to establish links and shape relationships that enable or facilitate the implementation of projects. A. Frączkiewicz-Wronka (2013, p. 173) defines inter-organizational collaboration as "the field of interaction created by separate and interdependent actors, where the attunement of interests takes the institutional form of formalized collective actors or informal character of ad hoc networks and intersects with the established order of economic exchange relationships". Such relationships can be defined as voluntary links between systems, organizations and individuals that engage in certain joint activities while maintaining their autonomy. Entities operating within that structure may maintain stronger or weaker relations, which are nevertheless geared towards a common vision.

In an advanced perspective, inter-organizational collaboration prompts a network of flexible relations between the entities involved. The outcomes of implementing activities under the inter-organizational collaboration network concern primarily (Sienkiewicz-Małyjurek 2012, p. 53):

- the area of relationships - transfer of information and knowledge, increase of trust and partnership relations between network participants,

- the implementation of activities - reducing the risk of failure, improving the performance and flexibility of operations, improving the flow of resources, faster mobilization through increased coordination and integration of activities,

- development - innovation, creation of knowledge, strengthening synergistic effect, complementarity.

Cross-sector collaboration is currently a prerequisite for solving accumulative social problems, but empirical research in this field is very limited (Kolk, Lenfant 2015, pp. 287-303). Appropriate arrangement of cooperation between various entities may lead to proper identification, and in turn, proper solutions to social issues appearing in public space. New forms of cooperation between various entities, especially cross-sector partnerships, require a special type of management, whose task is to catalyze conflicts of interest and coordinate 
joint activities - hence the need to consider them in a theoretical light. Therefore, it seems reasonable to refer to in-depth literature studies on the nature, characteristics and determinants of cross-sector partnerships in this consideration. The purpose of this article is to systematize knowledge about the possible forms and principles of cross-sector cooperation, and to discuss key aspects of this type of partnerships. The method of systematic literature review was used to accomplish that goal. The research covered articles appearing in the Ebsco Business Source Complete database, in which the search was run for full-text, peer-reviewed articles published in scientific journals in 2000-2017, containing the following key words in the abstract: partnership, cross-sector cooperation, public-social partnership. The current state of knowledge regarding cross-sector partnerships is quite modest, and empirical studies so far have been fragmentary and subject to conceptual and methodological limitations. The results of this review allow to put forward a hypothesis about the emergence of a cognitive gap in the area of exploration of the analysis of the content of inter-organizational links in relation to cross-sector cooperation. Therefore, it is important to conduct further empirical research in the future, which will identify the underlying factors of such cooperation, determine methods of its creation, and indicate relevant trends in this area.

\section{The essence and scope of partnership}

The concept of partnership is interpreted and presented in the literature in various ways. Generally speaking, it means "co-participation in something". To determine partnership, wording such as cooperation, coordination, collaboration, working groups, integrated jointly operating organizations or networks are used. Semantically, partnership is identified as an interagency, interprofessional collaborative, joint-up working, joined-up thinking, whole systems or holistic approach (Frączkiewicz-Wronka, 2013, p. 173).

Analysis of previous work on the subject of partnership allows to state that some researchers have focused primarily on creating value for the organization, while others have considered (external) management processes and social effects of joint activities (Kolk, Lenfant 2015, pp. 287-30). Despite the deficiencies due to the ambiguity of the definition of the concept of partnership, it is nevertheless possible to indicate some of its characteristic elements (Frączkiewicz-Wronka 2013, pp. 175-176):

- it can be established between organizations, community groups, public entities, individuals,

Cross-sector partnership as a determinant of development - the perspective of public 
- organizations that form them share a common goal or goals, vision, mission and interests,

- its participants accept joint rights, share resources and responsibilities,

- it is characterized by innovative structures and processes,

- organizations that form it are autonomous and independent,

- organizations that form it undertake actions to improve and increase access to social services,

- partners involved in the delivery of social services are equal, even if the actual equality of partners is rarely the case in real life,

- it expresses strong appreciation of the aspect of mutual trust in joint undertakings.

Partnership is, thus, a form of collaboration or cooperation, whose specific nature stems from its characteristics. The first of these characteristics is social participation observed already at the stage of perceiving a common problem and working out ways to solve it. The second determinant is the strength of collaboration, which is based on consensus and negotiation, transparency of action and voluntary participation of individual partners. The third manifestation of partnership is the fact of setting out convergent goals, the implementation of which is to be based on jointly prepared strategies and action plans, together with using the resources of individual partners. The fourth characteristic is trust, which is the foundation of all kinds of undertakings (see: Kołomycew 2013, p. 259).

Partnership within the EQUAL meaning is treated as undertaking actions based on a common strategy and development of an integrated approach to multidimensional problems. As such, individual partners of a partnership combine efforts and resources to find innovative solutions for common goals and jointly defined problems. According to A. Szromnik, „partnership between organizations or individuals - market participants means an arrangement of mutual relations that leads to simultaneous implementation of business objectives of both parties" (Szromnik 2006, p. 6).

Then, according to the OECD report, partnership is a system of formalized cooperation between several institutions, based on a legally contracted or informal agreement, links within cooperative activities and jointly adopted plans (Furmankiewicz 2006, pp. 117-118). OECD experts emphasize that partnerships play the role of a development coordinator. There are two basic ideas underlying the promotion of partnership principles. First, the current challenges, needs and opportunities for economic and social development are, as practice shows, too complex for individual institutions to properly address them. In this context, 
partnership is based on the assumption that complex problems can only be solved when organizations with complementary skills actively cooperate, developing synergies, sharing ideas, objectives, risks, opportunities, commitments and tasks, as well as competences and resources. Second, understanding the fact that economic growth and the ability to adapt to the ongoing social changes do not depend solely on the amount of available human, natural and material capital, but also on the developed social capital (Lechwar 2010, pp. 206-207).

In recent years, the subject of partnership appeared in the considerations of researchers with reference to the social capital theory due to the constant search for the answer to the question in which conditions society and the economy develop best. The most frequently occurring elements in the definitions of social capital are: participation in networks of relations and relationships, access and use of resources (in particular non-material ones, i.e. knowledge and skills), shared standards and values, trust, generating specific benefits for achieving goals (Skawińska 2012; Wyrwa 2014).

D. Jamali, M. Yianni and H. Abdallah argue that the relational aspects of trust, communication and coordination of activities contribute to improving the quality of relationships, enable cooperative behavior, weaken opportunist attitudes and may lead to new ways of associating. Generally speaking, these elements have been considered important factors underlying an innovative partnership, one that constantly seeks new and better ways to work in teams (see: Walters, Anagnostopoulos 2012, pp. 417-433).

Partnerships can also serve as a regional development tool. According to the Polish National Strategy of Regional Development, partnership is defined as „participation, joint decision-making and co-responsibility of public entities in developing a policy and accomplishing its goals. Partnership of public entities (i.e. national, regional, local - provincial, municipal, communal and other) and non-public institutions relies on a joint effort to set out regional policy objectives and collaboration in the implementation of joint undertakings contributing to the successful pursuit of those objectives (...) To increase efficiency of these activities, relationships between all actors must be based on mutual trust. A properly implemented regional policy will provide support for relevant processes in this area" (Krajowa Strategia Rozwoju... 2010, pp. 74-75).

The benefits of collaboration within a partnership are multifaceted. Partnerships may (Lechwar 2010, p. 208):

- help mitigate conflicts between various participants in a given undertaking,

- be a way of distributing the risk among a wider group of participants, and thus encourage taking more creative actions,

Cross-sector partnership as a determinant of development - the perspective of public 
- increase coordination and ensure the inclusion of an undertaking in the local government system,

- form the basis for pursuing a common objective,

- be considered a mechanism for creating and maintaining social capital,

- be a creative way to implement certain new services or improve the provision of existing ones,

- provide a means of controlling the level of service delivery costs and improving the quality of their performance, plus contribute to a greater sensitivity of services provided to the needs of recipients.

There are many different types and models of the functioning of partnerships. Currently, partnerships are strongly diversified depending on the objective, adopted structure, organizational form and area in which they operate. For these reasons, it is difficult to introduce any particular classification system for partnerships. In order to organize knowledge and stress the diversity of partnerships, it can be pointed out that the basic factor differentiating these structures is the degree of their formalization. These can be highly formalized solutions, which include partnerships for employment, "activation" and support of the labor market. Partnerships established in rural areas under the LEADER approach, i.e. local action groups (Kołomycew 2013, pp. 262-263), can also be included in highly formalized partnerships.

Considering different ways of achieving goals through partnerships, strength of connections and formality of the agreements that underlie them, three basic types of partnerships can be distinguished. namely: networks, coordinating partnerships and executive (project) partnerships (see: Eichner, Bańczyk 2011, pp. 12-14).

Networks can be defined as a set of independent units forming a joint structure in order to carry out specific and determined activities. It is a group of autonomous organizations aiming at accomplishing a goal that cannot be achieved by any of them individually. Networks consist of organizations that are related by structural interdependencies, where no single organization is subordinate to another because of its formal position (Austen 2012, p. 172). The goal of a network-based partnership is primarily the exchange of information and experience. Members can join or leave without much difficulty, thus not exerting too much influence on the existence of the partnership itself. Models of processes and structures within networks are very informal, too. Member organizations usually do not give up their autonomy. The allocation of resources takes place mostly in the field of ideas, messages, reports, briefs, etc. Membership of the organization in one network does not exclude its membership in others. 
Federation is a variation of the network partnership. It involves grouping partners into broader agreements aimed at better implementation of public tasks and lobbying in order to develop a common policy for solving problems as identified by the federation (see: Eichner, Bańczyk 2011, p. 12).

Coordinating partnerships are not clearly profiled and their activities may span a wide range of social problems. Due to their diversity, different cases rely on the involvement of different interested parties or general participation in the decision-making and executive process is required. Thus, the partnership in question operates on the principle of task groups whose work is coordinated by their leaders. This solution ensures long-term functioning of the partnership, which means that it is a strategic solution with broadly outlined goals (Kołomycew 2013, pp. 262-263).

In executive (project) partnerships, the entire pool of partner forces and resources is involved in the implementation of one action or the implementation of one project. Partnerships of this kind are generally short-term or mediumterm, pursuing one specific objective and operating within one specific area. Executive partnerships generally conclude their activity at the end of the implementation of the project they have been established for (Eichner, Bańczyk 2011, p. 13).

\section{Conditions for the functioning of cross-sector partnerships}

One of the ways to support social development is to form cross-sector partnerships, or institutional forms of collaboration between entities from various sectors of the economy - public, financial and social (Furmankiewicz 2006, p. 117).

Cross-sector partnerships are both the next stage of joint governance in public policy, continually on the rise since the 1990s, and the decision-making mechanism promoted by the European Union to support the implementation of community policies (Kołomycew, Pawłowska 2013, p. 63).

Cross-sector partnership is a voluntary collaboration of entities from the three sectors in the process of identifying and defining problems that concern public tasks and jointly working towards their solution, while maintaining the principle of equality in sharing resources, accountability, risks and benefits.

Cross-sector partnership - as defined by the Overseas Development Institute (ODI) and the International Business Leaders Forum (IBLF) - is a voluntary, informed and strategic alliance of partners representing various sectors: public, commercial and non-governmental. It is concluded in order to implement

Cross-sector partnership as a determinant

of development - the perspective of public 
the assumptions of sustainable development and all partners jointly bear the risks and share the benefits resulting from accomplishing both collective and individual goals. The partnership principle is based on the inclusion of a specific type of pluralism. In relation to social policy, this means involvement of various sectors in developing a new model of social policy, which allows to overcome sectoral limitations and use their potential, without which the implementation of the idea and the principle of sustainable development would not be possible (Kaliszewska 2012, p. 21).

The literature indicates numerous advantages of the concept of organized cross-sector collaboration. Organization of various entities into partnerships is to promote the creation of added value, increase resources (budget), establish new networks of links between individuals, enhance mutual understanding and prevent duplicating efforts to meet local needs. Crosssector partnerships are to support the building of understanding between local actors, the creation of joint local strategies and the coordination of activities. They facilitate access to various skills, promote innovation, strengthen local identification of groups and social entities from a given territory, improve the competitiveness of a given subregion, increase sensitivity to local needs, improve the financing of activities, include support of the private sector, increase social participation and reduce conflicts between local entities (Furmankiewicz 2006, pp. 119-120).

In the case of establishing a cross-sector partnership, the partners are given the opportunity to (see: Kaliszewska 2012, p. 30):

- implement innovative forms of collaboration,

- use the potential, skills and substantial knowledge in practice,

- multiply the potential by using the full range of financial, staff and technical capabilities of each party,

- expand new flexible structures through establishing cooperation networks, generating channels of activity and commitments for new partners,

- graps and internalize the key objectives of cooperation by mutual identification of their capabilities,

- develop integrated and effective activities,

- create the basis for social trust.

Establishing an effective cross-sector partnership is possible when the following conditions are met (see: Kaliszewska 2012, p. 24):

- transparency of communication, allowing to build trust and mutual understanding,

- clarity of functions, duties and rights, 
- understanding principles and objectives,

- understanding differences in organizational culture, skills, time commitment of parties,

- focus on the pursuit of mutual benefits so as to accomplish individual and common goals,

- identification of the needs of local stakeholders and support the potential rather than dependencies.

Within cross-sector partnerships, bi-sector partnerships can be distinguished, i.e.: public-social, private-social and public-private partnerships. There is also a tri-sector form of partnership, i.e. public-private-social partnership.

Public-social partnership is a model of mutual dependencies between various public and social entities, in which at least some of the links differ from hierarchical relations. According to the assumptions, organizations forming a partnership should have an equal bargaining power and the majority of decisions should be made on the basis of consensus. An important distinction of public-social partnerships is the need to work out certain forms of organization, principles of operation, which brings them closer to the organization and more broadly fits into the concept of an organizational project (Frączkiewicz-Wronka, Bratnicki 2013, pp. 348-349).

Public-social partnership occurs when cooperation in the performance of public tasks between the parties is not incidental, but is implemented over a longer period of time and repetitive. This partnership can also lead to the creation of organizational foundations for collaboration (Baron-Wiaterek, Grzanka 2014, p. 218).

As termed by A. Frączkiewicz-Wronka (2014, p. 416), public-social partnership is "a specific metaorganization whose characteristic is that it is sustained by more than a set of principles or a rigid structure resulting from a developed organizational scheme - it is a living organizational form with visible architecture, indicating, on the one hand, institutionalization and, on the other, strong appreciation of the non-measurable aspects of the relationships on the basis of which it was founded and now operates. The fact that managers can freely cross organizational boundaries and use their transdisciplinary knowledge to define a vision of what can be accomplished through partnership determines its success".

Public-social partnership implies a voluntary collaboration of representatives of public and social institutions, which are primarily aimed at accomplishing common goals, sharing mutual resources and experiences. This requires compliance with established principles and developing appropriate forms of

Cross-sector partnership as a determinant of development - the perspective of public 
action in accordance with applicable legal solutions. These are the principles of: subsidiarity (obtaining support for self-government activities), sovereignty (organizational independence of each of the collaborating parties and the right to define and solve problems), partnership (preparation, implementation, monitoring and financing of programs), fair competition (accounting for the market mechanism), openness (transparency of functioning at every stage of collaboration, sharing information about intentions and goals and resources allocated for tasks), performance (optimal use of resources at the disposal of selfgovernment and the cooperating organization) (see: Baron-Wiaterek, Grzanka 2014, p. 221).

More specifically, public-social partnership can be defined as all kinds of undertakings, projects and initiatives that are jointly planned, developed, implemented and pursued in a systematic, sustainable way using innovative methods and measures, focused on the development of the local socio-economic environment as well as building local identity and a socially cohesive local ambience. It is a common, long-term coalition of partners in a particular area that maintains the principle of equality in sharing resources, accountability, risks and benefits (Kalisiak-Mędelska 2013, p. 75).

In the literature, public-social partnership is therefore defined as a form of collaboration between organizations from various sectors of the economy, which is formed with a view to solving social problems and within which there is a mutual understanding of responsibility and resource commitment. There are two main theoretical approaches that form the basis for the study of public-social partnerships. The first concept perceives the development of partnerships in an instrumental way, maintaining that partner organizations are established to safeguard private interests, and only then - to solve social problems. This idea is based on the theory of resource dependency, which means that organizations are established in the face of an insecure environment. Thanks to the development of the partnership, its participants are able to access additional resources that allow greater flexibility and enable them to solve problems they normally would not be able to solve themselves. The second theoretical approach has been described as a platform for social problems in which the partnership is developed mainly as a way of solving a specific social problem. Proponents of this concept argue that non-profit organizations are increasingly seeking to raise awareness of issues related to corporate social responsibility, which makes them more willing to cooperate and build relationships with enterprises (Walters, Anagnostopoulos 2012, pp. 417-433). 
The process of implementing public-social partnerships is highly complex. In order to eliminate potential implementation problems, models have been developed that determine the order of development stages of this type of partnership. Traditional models usually focus on three main stages separately i.e. formation, implementation and results - whereas more recent models tend to combine these three stages (table 1).

Table 1. Stages of development of public-social partnership

\begin{tabular}{|c|c|}
\hline Authors & Partnership stages and micro-level processes \\
\hline $\begin{array}{l}\text { S. Waddell, L.D. } \\
\text { Brown (1997) }\end{array}$ & $\begin{array}{l}\text { Identifying preconditions for cooperation } \\
\text { Convening partners } \\
\text { Setting shared directions } \\
\text { Implementing action strategies } \\
\text { Institutionalising }\end{array}$ \\
\hline $\begin{array}{l}\text { B.K. Googins, S.A. } \\
\text { Rochlin (2000) }\end{array}$ & $\begin{array}{l}\text { Defining clear goals } \\
\text { Obtaining senior level commitment } \\
\text { Engaging in frequent communication } \\
\text { Assigning professionals to lead the work } \\
\text { Sharing the commitment of resources } \\
\text { Evaluating progress/results }\end{array}$ \\
\hline $\begin{array}{l}\text { J.M. Bryson, B.C. } \\
\text { Crosby, M. Middle- } \\
\text { ton Stone (2006) }\end{array}$ & $\begin{array}{l}\text { Initial conditions: general environment - turbulence, competitive and insti- } \\
\text { tutional elements } \\
\text { Sector failure: direct antecedents - conveners, general agreement on the } \\
\text { problem, existing relationships or networks } \\
\text { Process: formal and informal - forging agreements, building leadership, } \\
\text { building legitimacy, building trust, managing conflict, planning } \\
\text { Structure and governance: formal and informal - membership, structural } \\
\text { configuration, governance structure } \\
\text { Contingencies and constraints: type of collaboration, power imbalances, } \\
\text { competing institutional logics } \\
\text { Outcomes and accountabilities: } \\
\text { outcomes - public value; first-, second- and third-order effects; resilience } \\
\text { and reassessment } \\
\text { accountabilities - inputs, processes and outputs; results management sys- } \\
\text { tem; relationships with political and professional constituencies }\end{array}$ \\
\hline $\begin{array}{l}\text { M.M. Seitanidi, A. } \\
\text { Crane (2009) }\end{array}$ & $\begin{array}{l}\text { Partnership selection } \\
\text { Deciding associational form, assessing the different options, informal risk } \\
\text { assessment process (internal vs. external) } \\
\text { Partnership design } \\
\text { Experimentation, adaptation, operationalisation } \\
\text { Partnership institutionalisation } \\
\text { Relationship mastering, personal familiarisation } \\
\text { Exit strategy }\end{array}$ \\
\hline
\end{tabular}

Cross-sector partnership as a determinant of development - the perspective of public 


\begin{tabular}{|c|c|}
\hline $\begin{array}{l}\text { D. Jamali, T. Keshi- } \\
\text { shian (2009) }\end{array}$ & $\begin{array}{l}\text { Partnership initiation } \\
\text { Preparation, negotiation, criteria for partner choice, motives, goals of part- } \\
\text { nership, centrality alignment with mission, importance, specificity } \\
\text { Partnership execution } \\
\text { Scope of activities, magnitude of resources, trends of investment, level of } \\
\text { engagement, leadership involvement, communication, complexity of pro- } \\
\text { cesses, efficiency, equity } \\
\text { Partnership evaluation } \\
\text { Evaluation, future expectations, learning }\end{array}$ \\
\hline
\end{tabular}

Source: Walters, Anagnostopoulos 2012, s. 420

In recent years, partnerships have not only been used in practical activities undertaken to manage public sector more effectively, but they have also been the subject of scientific research conducted in the field of management. However, it should be emphasized that no grand theory has been developed so far to include research studies on cooperation in partnerships. Depending on the reference theory adopted, the legitimacy of creating inter-organizational links can be explained by the desire to reduce production costs and transaction costs (transaction costs theory), the desire to gain access to unique or needed resources (resource theory), the desire to increase organization or market efficiency (strategic choice theory), the willingness to reduce market uncertainty (stakeholder theory), the desire to absorb external knowledge (organizational learning theory), or the willingness to exert isomorphic market pressure (institutional theory).

\section{Conclusions}

Partnerships are becoming an increasingly common form of collaboration, in which organizations from different sectors work together towards achieving the intended goal (Waddock 1991; Selsky, Parker 2010). Establishing partnerships to solve social problems is an important element of the concept of "governance", based on the conviction that a single entity does not have sufficient resources for the independent exercise of public authority or committing to public undertakings. This implies, among other things, the readiness to build organizational networks, thereby increasing operational efficiency and effectiveness.

Cross-sector social partnerships are projects formed primarily to solve social "metaproblems" that cannot be solved by a single organization alone. They include joint, collective actions and their goals concern both short-term 
and long-term outcomes in the field of social policy. Innovative forms of crosssector collaboration through the implementation of initiatives that are socially important generate enormous potential in the sphere of strategies for reducing social problems. The cross-sector partnership formula enables (Flieger 2016, p. 116; Kaliszewska 2012, p. 22):

- creating a new, dynamic network of connections, allowing partners to more effectively influence social goals,

- cooperation based on strategic partnership,

- an open communication system between the partners, which contributes to the rapid and effective exchange of information,

- joint decision-making by all network participants,

- a negotiation method for coordinating the activities of the partners,

- flexibility - configuration of cooperation (relations) between network participants has no structural or formal limitations, each partner can join or leave the network voluntarily - flexibility is also observed in the process of adapting to changing customer needs, which is one of the most important advantages of this method of cooperation,

- complementarity of resources and skills - the network allows for the sharing (exchange) of resources, including knowledge that would otherwise not be available to a given institution operating outside the network,

- cooperation between various entities and access to external resources that foster innovative attitudes,

- reducing operating costs by means of reducing competition - entities cooperate instead of competing with each other,

- greater opportunities to offer the customer more complex and better suited products or services,

- understanding the value and nature of individual sectors, thus contributing to greater social integration and stability.

The cross-sector collaboration discussed in this article is a relatively new phenomenon in the public sector, whose genesis should be associated with the transformation of management instruments from business organizations into non-profit organizations and the growing popularity of the concept of cooperation between organizations and sectors. Establishing network organizations is a response to the challenges of the practice under which different complex problems increasingly require various resources and skills to be solved, while these resources and skills are often had by many economic entities - not only enterprises, but also public institutions and social organizations (FrączkiewiczWronka 2014, p. 397).

Cross-sector partnership as a determinant of development - the perspective of public 
Comparing the benefits and threats of cross-sector cooperation, as described in the literature, an overall prevalence of positive assessments and empirical examples can be observed. The literature indicates numerous advantages of the concept of organized cross-sector cooperation in public management. A more efficient and effective performance of public services requires at least the coordination of activities, and often also institutional forms of cooperation. Cooperation can lead to the effect of complementarity and synergy of scattered resources. Economies of scale, or the effect of exceeding critical mass - the threshold of cost-effectiveness of implementation of some projects and technologies is also crucial. The exchange of information and good practices is most often mentioned as a benefit of cooperation. It allows to use the existing experience and avoid duplicating efforts in further works. This is the most common model of cooperation, based primarily on interpersonal contacts, which do not require any formalization.

Observing the current practice of action indicates that organizations acting together, jointly choosing goals and, consequently, deciding on how to use their own resources, often gain the ability to create new structures. These new structures - as a consequence of using the benefits of implementing the idea of cooperation - can generate together more positive results than each organization separately. These benefits of cooperation stem mainly from general advantages of group activity, which also includes economies of scale (more people in a group results in an increased level of production), synergy (when a group achieves better results than the most effective unit individually), and achieving critical mass, i.e. a certain level of specific resources (e.g. skills, knowledge, financial resources, etc.) necessary to embark on a given venture.

The recent popularity of inter-organizational relations is explained by the wide range of their positive implications. Nevertheless, in the light of the current literature, a decision to establish cooperation ties can be both strengthened and weakened by various internal and external factors. Significant negative effects of inter-organizational ties are: uncertainty and volatility of expenditures for maintaining relationships, excessive involvement and investing in relationships, dependence on partners, loss of identity, as well as the risk of losing knowledge and skills.

In summary, further research directions emerging from the presented analyses should be indicated. The consistency of the obtained results makes it possible to put forward a recommendation that research on cross-sector cooperation should be approached from various research perspectives. As 
regards the subject at hand, an important direction of future research will be to assess the effectiveness of the cross-sector partnership and answer the question of whether this form of organizing activities is an effective way of providing public services. Particular emphasis should be placed on identifying conditions and analyzing the level of inter-organizational cooperation. When assessing partnership effectiveness, it is necessary to first examine the impact of the partnership on the community, determine its value for individual member organizations, and measure real costs and benefits that have been achieved as a result of this cooperation. The need for further research in this area also implies that cooperation is increasingly the subject of interest for researchers, although many analyses are embedded in the context of commercial organizations, which makes the results of previous studies on partnership not always useful in considering networks operating in the public sector. It can be concluded that the current state of knowledge about cross-sector partnerships, which is of interest to public management, is still insufficient.

\section{Summary}

Cross-sector partnership as a determinant of development - the perspective of public management

Challenges faced by organizations in the area of public management today force them to seek new organizational forms to build a competitive advantage. In contemporary public management, two trends in particular can be observed. The first is to depart from repeatability and duplication of actions, and to follow instructions with a view to focusing on creativity and efficiency in solving problems. The second is to create partner relations not only within the public sector, but also in cooperation with organizations from other sectors.

The article systematizes knowledge about cross-sector cooperation and is an attempt to organize research trends in this area. This paper is the result of literature research carried out in the form of systematic review of available sources - databases that aggregate scientific publications specific to this field. The article presents an integrated overview of cross-sector issues, allowing to establish the basis for future research.

Keywords: partnership, cross-sector cooperation, public-social partnership.

Cross-sector partnership as a determinant of development - the perspective of public 


\section{Streszczenie}

Partnerstwo międzysektorowe jako determinanta rozwoju - perspektywa zarządzania publicznego

Wyzwania, przed jakimi stają współczesne organizacje w obszarze zarządzania publicznego, zmuszają je do poszukiwania nowych form organizacyjnych pozwalających na budowanie przewagi konkurencyjnej. We współczesnym zarządzaniu publicznym wyraźnie zauważalne są dwie tendencje. Pierwsza to odchodzenie od powtarzalności i powielania działań oraz wykonywania instrukcji na rzecz koncentrowania się na kreatywności i efektywności w rozwiązywaniu problemów. Druga to tworzenie partnerskich relacji nie tylko w obrębie sektora publicznego, ale również we współdziałaniu z organizacjami z innych sektorów.

Artykuł systematyzuje wiedzę dotyczącą współpracy międzysektorowej, jest przy tym próbą uporządkowania nurtów badawczych $w$ tym obszarze. Artykuł powstał jako wynik przeprowadzonych badań literaturowych, mających charakter systematycznego przeglądu dostępnych źródeł - baz danych agregujących publikacje naukowe w przedmiotowym zakresie. W artykule przedstawiono zintegrowany przegląd zagadnień dotyczących współpracy międzysektorowej pozwalający ustanowić podstawę dla przyszłych badań.

Słowa

kluczowe: partnerstwo, wspótpraca międzysektorowa, partnerstwo publiczno-spoteczne.

JEL

Classification: L31, L32, L33

\section{References}

1. Austen A. (2012), Wyzwania badawcze w obszarze pomiaru efektywności partnerstw lokalnych, "Współczesne Zarządzanie", No. 3, pp. 172-182.

2. Baron-Wiaterek M., Grzanka I. (2014), Partnerstwo publiczno-społeczne we wspólnotach terytorialnych, "Zeszyty Naukowe. Organizacja i Zarządzanie", Politechnika Śląska, Issue 76, pp. 217-229.

3. Bryson J.M., Crosby, B.C., Middleton Stone M. (2006), The Design and Implementation of Cross-Sector Collaborations: Propositions from the 
Literature, "Public Administration Review", Vol. 66, Issue 1 (Special Issue), pp. 44-55.

4. Domański J., Kitzman K. (2016), Wspótpraca wyborem strategicznym przedsiębiorstw $i$ organizacji non profit, "Prace Naukowe Uniwersytetu Ekonomicznego we Wrocławiu", No. 420, pp. 55-65.

5. Eichner M., Bańczyk P. (2011), Czar partnerstw. Tworzenie partnerstw i zarządzanie nimi, Dom Współpracy Polsko-Niemieckiej, Gliwice.

6. Flieger M. (2016), Optymalizacja funkcjonowania instytucji administracji publicznej poprzez kooperacje w sieci, "Prace Naukowe Uniwersytetu Ekonomicznego we Wrocławiu", No. 421, pp. 114-127.

7. Frączkiewicz-Wronka A. (2013), Partnerstwo publiczno-społeczne jako instrument wielosektorowej polityki spotecznej - perspektywa zarzadzania publicznego, "Prace Naukowe Uniwersytetu Ekonomicznego we Wrocławiu", No. 277, pp. 165-181.

8. Frączkiewicz-Wronka A. (2014), Identyfikacja charakteru powiązań wystepujacych $w$ ramach projektu organizacyjnego typu partnerstwo publicznospołeczne i ich znaczenie dla efektywnego dostarczania ustug społecznych, "Prace Naukowe Wałbrzyskiej Wyższej Szkoły Zarządzania i Przedsiębiorczości", Vol. 27 (2), pp. 389-420.

9. Frączkiewicz-Wronka A., Bratnicki M. (2013), Architektura organizacyjna $z$ perspektywy partnerstwa publiczno-społecznego, "Prace Naukowe Wałbrzyskiej Wyższej Szkoły Zarządzania i Przedsiębiorczości", Vol. 22 (2), pp. 343-381.

10. Furmankiewicz M. (2006), Wspótpraca międzysektorowa w ramach "partnerstw terytorialnych" na obszarach wiejskich w Polsce, "Studia Regionalne i Lokalne", No. 2(24), pp. 117-136.

11. Googins B.K., Rochlin S.A. (2000), Creating the Partnership Society: Understanding the Rhetoric and Reality of Cross-Sectoral Partnerships, "Business and Society Review", Vol. 105, Issue 1, pp. 127-144.

12. Jamali D., Keshishian T. (2009), Uneasy Alliances: Lessons Learned from Partnerships Between Businesses and NGOs in the Context of CSR, "Journal of Business Ethics", Vol. 84, Issue 2, pp. 277-295.

13. Kachniarz M. (2014), Kooperatywność samorzadów lokalnych, "Prace Naukowe Uniwersytetu Ekonomicznego we Wrocławiu", No. 339, pp. 36-48.

14. Kalisiak-Mędelska M. (2013), Partnerstwo lokalne - istota i znaczenie na przykładzie lokalnych grup działania, "Biblioteka Regionalisty", No. 13, pp. 73-96.

15. Kaliszewska M. (2012), Partnerstwo międzysektorowe w ekonomii spotecznej wspótpraca z administracją publiczną i biznesem, [in]: Handzlik A., Głowacki J. (ed.), Partnerstwo - współpraca międzysektorowa w realizacji celów społecznych, Uniwersytet Ekonomiczny w Krakowie, Małopolska Szkoła Administracji Publicznej, Kraków. 
16. Kolk A., Lenfant F. (2015), Cross-Sector Collaboration, Institutional Gaps, and Fragility: The Role of Social Innovation Partnerships in a Conflict-Affected Region, "Journal of Public Policy \& Marketing", Vol. 34(2), pp. 287-303.

17. Kołomycew A. (2013), Partnerstwa jako interesariusze w modelu rzadzenia wielopodmiotowego. Specyfika, tworzenie i funkcje w jednostkach terytorialnych, “Nierówności Społeczne a Wzrost Gospodarczy”, No. 34, pp. 255-274.

18. Kołomycew A., Pawłowska A. (2013), Partnerstwa międzysektorowe w rozwoju obszarów wiejskich na przykładzie Lokalnych Grup Działania w województwie podkarpackim, "Studia Regionalne i Lokalne", No. 2, pp. 62-80.

19. Kożuch B. (2007), Nauka o organizacji, Wydawnictwo CeDeWu, Warszawa.

20. Kożuch B. (2011), Skuteczne wspótdziatanie organizacji publicznych $i$ pozarzadowych, "Monografie i Studia Instytutu Spraw Publicznych Uniwersytetu Jagiellońskiego", Kraków.

21. Krajowa Strategia Rozwoju Regionalnego 2010-2020: Regiony, Miasta, Obszary Wiejskie (2010), Ministerstwo Rozwoju Regionalnego, Warszawa.

22. Lechwar M. (2010), Partnerstwo jako determinanta modernizacji regionu, "Nierówności Społeczne a Wzrost Gospodarczy", Issue 17, pp. 205-214.

23. Seitanidi M.M., Crane A. (2009), Implementing CSR Through Partnerships: Understanding the Selection, Design and Institutionalisation of NonprofitBusiness Partnerships, "Journal of Business Ethics", Vol. 85, Supplement 2, pp. 413-429, DOI 10.1007/s10551-008-9743-y

24. Selsky J.W., Parker B. (2010), Platforms for Cross-Sector Social Partnerships: Prospective Sensemaking Devices for Social Benefit, "Journal of Business Ethics", Vol. 94, Supplement 1, pp. 21-37, DOI 10.1007/s10551-011-0776-2

25. Sienkiewicz-Małyjurek K. (2012), Sieciowe ujęcie wspótpracy międzyorganizacyjnej w zarządzaniu kryzysowym, "Współczesne Zarządzanie", No. 3, pp. 51-60.

26. Skawińska E. (red.) (2012), Kapitat społeczny w rozwoju regionu, PWN, Warszawa.

27. Szromnik A. (2006), Partnerstwo marketingowe $w$ regionie. Problemy teoretyczno-koncepcyjne, "Zeszyty Naukowe Akademii Ekonomicznej w Krakowie", No. 694, pp. 5-18.

28. Waddell S., Brown, L.D. (1997), Fostering Intersectoral Partnering: A Guide to Promoting Cooperation Among Government, Business, and Civil Society Actors, "Institute for Development Research Reports", Vol. 13, No. 3, pp. 1-26.

29. Waddock S.A. (1991), A Typology of Social Partnerships Organizations, "Administration \& Society", Vol. 22, No. 4, pp. 480-515.

30. Walters G., Anagnostopoulos Ch. (2012), Implementing corporate social responsibility through social partnerships, „Business Ethics: A European Review", Vol. 21(4), pp. 417-433, DOI: 10.1111/j.1467-8608.2012.01660.x.

31. Wyrwa J. (2014), Social capital and development of an enterprise, „Management”, Vol. 18, No. 1, pp. 280-300. 